\title{
The Development and Implementation of Layered Teaching in College English Based on Students' Needs
}

\author{
Jie Zeng \\ School of Foreign Languages, Chengdu Normal University, Chengdu City, Sichuan Province, \\ 611130, China
}

Key words: students' needs; college English; layered teaching; development; implementation

\begin{abstract}
Layered teaching mainly refers to the classification of students according to different situations and different needs of students. It's a teaching method in which teachers according to the characteristics of different categories of students to adopt appropriate teaching methods and teach students the appropriate content. This teaching method can to a certain extent meet the curriculum needs of students with different English levels. Based on the author's learning and practical experience, this paper firstly analyzes the related concepts of layered teaching, then probes into the role of layered teaching in college English, and finally puts forward the implementation scheme of college English teaching.
\end{abstract}

\section{Introduction}

The implementation of layered teaching method has a profound theoretical basis, including the principle of "individualized aptitude" proposed by Confucius, an Chinese educationist, the theory of "recent development area" proposed by Vygotsky, the famous psychologist of the former Soviet Union, and the Humanism Learning Theory represented by Maslow and Rogers. In fact, the differences between students can be regarded as a teaching resource. The way that teachers use this resource in the teaching process is to promote students at all levels to find their best room in developing.

\section{Related Concepts of Layered Teaching}

Layered teaching is a teaching organization where teachers in full consideration of the objective existence of the differences of the students in class design and implementation of teaching, every student treated differently. And teachers contrapuntally strengthen the learning guidance for various types of students in teaching, so that each student gets the best development. The connotation of layered teaching mainly consists of the following three aspects:

Firstly, the foothold of layered teaching is the individual difference between students. Because of the innate genetic factors and the influence of the acquired growth environment, there're some differences in characters, personalities and abilities of acceptance between student individuals. And these differences have a significant impact on students ' learning. To accomplish the established unified goal of teaching, college education must be fully aware of the individual differences between students. Only under the premise of fully recognizing the individual differences of students, taking "individualized" as the principle, implementing layered teaching according to the different levels of students, teaching content can be truly accepted by students.

Secondly, layered teaching is a kind of teaching organization. Layered teaching is a kind of teaching organization as well as class teaching. It's a teaching organization that based on the students' different receptive abilities and cognitive levels, layered teaching divides teaching content into several progressive layers, so that the difficulty of teaching content could adapt to the students' abilities and levels, and the students at the lower level can march towards the higher 
level after mastering the lower teaching content. And finally students of all levels would realize the teaching goal.

Thirdly, the goal of layered teaching is to create a variety of conditions and opportunities for students to try, choose, discover and develop, and to encourage students to move towards the higher level goal, thus promoting the good development of students' all aspects of personality potentials including intelligence, non-intelligence.

\section{The Role of Layered Teaching in College English}

Satisfy the learning requirements of students with different English proficiency. The teaching model that students at same level gather in a class can indeed meet the learning needs of students at different levels, and make students at different levels improved on the original basis. At the same time, teachers are positively affirmed that the implementation of layered teaching. The students in a class at the same level, the teacher is relatively relaxed about teaching with strong pertinence, and it is relatively easy to achieve teaching goals or effects.

Improve students' English learning achievement. By comparing the actual analysis, after attending layered teaching, students' CET-4 pass rate is 5\% higher on the average than students who are not participating in layered teaching. The implementation of layered teaching, using different teaching schedules for students at different levels, adapted to the needs of students at different levels, so that students pay off. In addition, because of the rolling system in layered teaching, some students, especially higher-level students with poor grades and lower-level students with good grades are always in a tense state, thus stimulating students' enthusiasm for learning.

Help teachers to carry out teaching research activities. As a researcher, teachers should consciously put their teaching work as the object of scientific research, and they should stand in the objective angle, constantly rethink their teaching work. Only in this way can the teaching level be improved. The implementation of layered teaching provides a platform for teachers ' research and innovation, and many problems to be solved become the direction of teaching improvement.

\section{The Implementation Scheme of Layered Teaching in College English}

Teaching goal stratification. The teaching goal stratification is the first link in the operation procedure of layered teaching mode, which can provide a criterion for the stratification of teaching content, the stratification of teaching organization, the stratification of teaching methods and the stratification of teaching evaluation, and also provides some chief basis for the advance in teaching process. Firstly, setting teaching goals needs to take the students' practical as the primary basis. The stratification of teaching objectives in the layered teaching mode is stratified by understanding and researching the students' existing cognitive structure, learning motivation, learning interest and other factors. Daqing Normal University is a developing undergraduate normal university, the student structure exists difference between undergraduate and specialty, recruitment and seec. Therefore, freshman carries on an English grading test. And the college unifies the students' English grades in entrance examination, divides the students initially into A, B, C level. In addition, it is important to emphasize that this is only a preliminary stratification. And the level of students can change by changing their own learning, i.e., rolling layering. Secondly, the college set different levels of goal, according to the stratification of students and combining College English Curriculum Requirements. In general, we adopt a flexible hierarchical target in college English teaching, as shown in table 1. 
Table 1 Elastic Stratification of Teaching Objectives

\begin{tabular}{ccc}
\hline Rank & $\begin{array}{c}\text { Student's English } \\
\text { level }\end{array}$ & Concrete subject \\
\hline A & a higher level & development \\
B & average & improvement \\
C & a lower level & foundation \\
\hline
\end{tabular}

The rank $\mathrm{A}$ is the developmental goal, mainly facing the students with high starting level, satisfying their higher requirements for knowledge;

The rank B is the improvement goal, mainly facing the students at the moderate level, so that they make further improvement on the basis of the original capacity;

The rank $C$ is the basic goal, mainly facing the lower beginning students, so that they consolidate the foundation and improve gradually.

Teaching content stratification. The stratification of teaching content is an important factor in the operating procedure of stratified teaching mode, and it is the embodiment of the goal of layered teaching. Firstly, according to the requirements of curriculum standards and the stratification of teaching objectives, the stratification of teaching content is embodied in static hierarchical contents, which include the standard of college English curriculum on campus, the hierarchical setting of syllabus, the hierarchical selection of textbooks and the compilation of lecture notes. Secondly, the stratification of teaching content embodies dynamic layered content, which teachers and students generate and experience together in college English teaching. This dynamic teaching content is based on the static and prescribed layered content. What teachers and students have learnt and experienced through the teaching activity can be either narrower or wider than the stipulation content, which depends on the teacher's ability to control the teaching activities throughout the teaching. Finally, whether it is static or dynamic teaching content stratification, both need that teachers and students cooperate closely in English teaching practice. And the college can finally achieve the hierarchical requirements of teaching objectives, complete the teaching tasks and constantly improve the students' comprehensive ability to use English.

Teaching organization method stratification. The educational activities of the college should not only clarify the stratification of teaching objectives, the stratification of teaching content, but also must be effectively carried out in a certain form. Layered teaching mode has changed the teaching organization form of traditional English public course, it adopts layered teaching organization method, i.e., the layered combination method of common activities of teachers and students in personnel, program and space-time relationship. An important breakthrough in the layered teaching mode of college English is that it changes the mode of giving instruction in the previous large class. According to the stratification of students at all levels, it uses small classes. This approach reduces the burden of teachers' large class teaching, strengthens the interaction between teachers and students, mobilizes the enthusiasm of students' participation in classroom teaching, and improves the students' interest in learning, which helps to cultivate students' comprehensive application ability in English.

Teaching evaluation stratification. The stratification of teaching evaluation is an important safeguard in the operating procedure of stratified teaching mode. To stratify teaching evaluation, first of all, the teaching evaluation standards should be stratified. In the teaching practice of college English, not only it should embody the basic standards of students, but also reflect the students' development of different standards and students' personality differences.

\section{The Realization Requirement of Layered Teaching in College English}

The realization requirement is all kinds of requirements to impel the layered teaching mode to exert effect and meet certain function, including teachers, students, textbooks, teaching media, 
teaching space. To sum up, the theoretical basis, functional objectives, operating procedures, combination of teachers and students, realization requirements of the structure of layered teaching mode occupy different positions, play different roles and have different functions. Combining with systematical comb and exploration that the practice of college English teaching makes for the structure of layered teaching mode, on the one hand, it strives to enrich and perfect the theory of layered teaching mode; on the other hand, it has importantly theoretical and practical significance to improve college English teaching quality.

\section{Summary}

The implementation of layered teaching mode in college English teaching is the requirement of implementing quality education, which is an effective way to improve students' comprehensive qualities, and truly embody the inevitable requirement that education should adapt to the diversity and individuation of talents. The practice proves that in the exploring process of practicing the stratified teaching mode, we give full play to our existing teacher resources, have achieved some teaching effect, face the students ' individual differences, respect the individuality development of the students. In the meantime, we promote the development of teachers, and take a new step to improve the teaching quality and practice the new teaching mode. However, implementing layered teaching mode in the practice and exploration of college English teaching, there exists theoretical and practical problems still to be solved. With the in-depth study of the layered teaching theory and the accumulation of teaching practice experience, the implementation of layered teaching mode in college English teaching will get a wider development space.

\section{References}

[1] Yang Yuhan. The differences in classroom questioning level of layered teaching in college English [J]. Foreign Language Teaching Theory and Practice, 2012,03:71-75.

[2] Guo Feixiao. Research on the dynamic layered teaching mode of college English based on information technology [J]. Foreign Language Audio-visual Teaching, 2013,06:71-75.

[3] Lu Dingyuan, Wan Yi, Cao shiyao. The exploration and practice of layered teaching mode in college English [J]. Crazy English (Teacher edition), 2009,03:4-7.

[4] Wang Xianrong. An experimental study on recessive layered teaching in college English [J]. Shandong Foreign Language Teaching, 2005,01:51-53.

[5] Chen Linxia. The importance of layered teaching in college English [J]. Heilongjiang Higher Education Research, 2005,01:151-153.

[6] Shu Haiying. The application of recessive layered teaching in college English teaching [J]. Educational Exploration, 2014,03:53-54.

[7] Liu Zehua. The research and practice of layered teaching management and quality assurance system in college English [J]. Higher Engineering Education Research, 2008,S1:27-30. 